\title{
Economic burden of cervical cancer in Malaysia
}

\author{
Sharifa Ezat Wan Puteh ${ }^{1}$, Paul Ng${ }^{2}$, Syed Mohamed Aljunid ${ }^{3}$
}

\begin{abstract}
Abstrak
Kanker serviks merupakan kanker kedua yang paling sering ditemukan pada wanita di Malaysia, sehingga menjadi beban biaya yang cukup besar. Namun, masih perlu diadakan perkiraan beban biaya yang diakibatkan oleh pulasan abnormal, penyakit servikal preinvasif dan invasif untuk menunjukkan jumlah biaya yang dialokasikan untuk masalah ini. Sebuah komite panel ahli telah menyusun sebuah alur klinis dan algoritme tata laksana penyakit servikal pre invasif dan invasif dari Juli-Desember 2006 di Malaysia. Dilakukan juga perhitungan biaya berdasarkan aktivitas untuk tiap alur klinis. Hasilnya dikonversi ke dalam Dollar AS. Biaya tata laksana kanker serviks stadium pre invasif adalah USD 420,150 (Kisaran: USD 197,158-879,679). Tata laksana kanker invasif (kasus baru) memakan biaya USD 51,533,233.44 (Kisaran: USD 32,405,399.69 - USD 87,850,566.87). Biaya yang diperlukan untuk menangani kasus-kasus yang sudah ada adalah USD 17,005,966.87 (Kisaran: USD 10,693,781.90 - USD 28,901,587.12). Jumlah total biaya yang diperlukan untuk menata laksana kanker serviks oleh penyedia jasa kesehatan di lingkungan publik adalah sekitar USD 75,888,329.45 (Kisaran: USD 48,083,804.60 - USD 129,014,768.40). Hasil penelitian ini menunjukkan bahwa modalitas pencegahan seperti skrining hanya menyumbangkan 10.3\% dari jumlah keseluruhan biaya penatalaksanaan kanker serviks. Sebagian besar biaya (67\%) adalah dari penanganan kanker invasif terutama yang pada stadium lebih lanjut, diikuti dengan penanganan kasus-kasus yang sudah ada (22\%) dan penyakit pre-invasif (0.6\%). Penelitian ini menunjukkan bahwa proporsi modalitas pencegahan di negara ini masih rendah, dan porsi biaya terbanyak berasal dari penanganan kanker serviks itu sendiri. Untuk itu, di negara ini perlu diadakan peningkatan skrining kanker serviks di masyarakat. (Med J Indones 2008; 17: 272-80)
\end{abstract}

\begin{abstract}
Cervical cancers form the second highest number of female cancers in Malaysia, imposing a substantial amount of cost burden on its management. However, an estimation of cost burden of abnormal smears, cervical pre-invasive and invasive diseases needs to be done to show how much spending has been allocated to the problem. An expert panel committee came up with the clinical pathway and management algorithm of cervical pre invasive and invasive diseases from July-December 2006 Malaysia. An activity based costing for each clinical pathway was done. Results were converted to USD. The cost of managing pre-invasive cervical cancers stage is USD 420,150 (Range: USD 197,158-879,679). Management of invasive cancer (new cases) costs USD 51,533,233.44 (Range: USD 32,405,399.69 - USD 129,014,768.40). The cost of managing existing cases is USD 17,005,966.87 (Range: USD 10,693,781.90 - USD 28,901,587.12). The total cost of managing cervical cancers by health care providers in a public setting is around USD 75,888,329.45 (Range: USD 48,083,804.60 - USD 48,083,804.60). The outcome of this study has shown that preventive modalities such as screening have only contributed to $10.3 \%$ of the total management cost of cervical cancer. The major cost contribution (67\%) came from treatment of invasive cancer especially at more advanced stages of cancer, followed by treatment of existing cases (22\%) and lastly on pre-invasive disease $(0.6 \%)$. This study revealed that proportion of preventive modality in this country was still low, and the major cost came from actual treatment cost of cervical cancer. Therefore, heightened public cervical cancer screening in the country is needed. (Med J Indones 2008; 17: 272-80)
\end{abstract}

Keywords : cervical cancers, pre invasive disease, HPV vaccination

1 Department of Community Health, Universiti Kebangsaan Malaysia, Kuala Lumpur, Malaysia

2 Department of Obstetrics \& Gynaecology, Universiti Kebangsaan Malaysia, Kuala Lumpur, Malaysia

3 United Nations University - International Institute of Global Health Malaysia, Kuala Lumpur, Malaysia
Cervical cancer was the second most common cancer after breast cancer in women globally until 1985, and ranked as the third most common cancer in 1990. Almost $80 \%$ of cervical cancer cases were diagnosed in developing countries, where it was the most common cancer in women. The high risk populations are in Africa, Latin Africa and Asian countries like India, Thailand, Philippines and Korea. ${ }^{1}$ 
The Malaysian National Cancer Registry Report ${ }^{2}$ found that the most frequently occurring cancers in Malaysian women were cancers of the breast, cervix, colon, ovary, leukemia and lungs, in that order. Cervical Cancer contributed about $12.9 \%$ of all female cancers with an age standardized incidence rate of 19.7 per 100,000 in Malaysia, and thus higher compared to other Asian and Western countries. Incidence rates were in general, highest among Chinese women (28.8), Indians (22.4) and lowest amongst the Malays (10.5). ${ }^{2}$

The cervical cancer screening program was established in 1969, following the integration of family planning services into the Maternal and Child Health Program of the Ministry of Health Malaysia.,4 The Pap smear screening program is planned, organized and evaluated by the Family Health Development Division, Ministry of Health Malaysia. Even though the program is targeted and offered to all sexually active women between the ages of 20 and 65 years, the screening interval recommended is three years following two initial consecutive negative smears taken one year apart.

Since the 1995 Healthy Life Style Campaign themed 'Cancer', Pap smear screening was made available to all females aged between 20 and 65 years and reinforced through the promotion of a healthy family. ${ }^{4}$ In 1999 , the Bethesda Classification System was introduced and was encouraged to be used by all health care providers for a standardized system of reporting., ${ }^{3,4}$ There are various agencies that provide Pap smear services such as the National Population and Family Development Board (Ministry of women, family and community development), Federation of Family Planning Association of Malaysia, private clinics and hospitals, university hospitals and army hospitals. The overall positive detection rate was $1.1 \%$ for year 2003.,

Voluntary and opportunistic cytological screening programs have been demonstrated to be effective even though there will be issues on sensitivity, specificity and population uptake. ${ }^{1,3-5}$ Cervical cytology is the most used method of screening., ${ }^{5,6}$ High Pap smear uptake in the developed countries and are probably responsible for the observed decline in the disease but this is not certainly seen in Malaysia where the population uptake is ranging from $30 \%-50 \%$ only. For cervical screening to be effective, it should be population based with wide coverage with the aim for at least $80 \%$ coverage of the population. ${ }^{6}$ The International Agency for Research on Cancer (IARC) ruled that there is enough evidence to classify HPV types 16 and 18 as carcinogenic.
Since then, there has been further development as more clinical trials are made and published. ${ }^{7,8}$ With a clinically effective vaccine available ${ }^{1,7}$, more efforts are concentrated to the development of cost and the effectiveness of health screening and interventions programs.

Through opportunity based conventional method, total cost of Pap smear screening in Malaysia, ${ }^{9}$ amounted to a base cost of USD 7.9 millions (Range: $\$ 5.5$ mil- $\$ 13.4$ mil). Abnormal pap smears cost $2 \%$ of total cost. This is slightly different from cost of cervical cancer screening and management in $\mathrm{UK}^{10}$ whereby the main bulk in the UK management of cervical cancer was in its screening program and thus avoiding the higher impact of cervical cancer treatment and extensive management. The fiscal burden of sustaining an effective screening program costs£ 150 millions in UK alone. ${ }^{11}$ Goldie et al. ${ }^{1}$ modeled, that the most cost effective strategy (incremental cost effective ratio of less than $\$ 60,000$ per quality adjusted life year) is to combine early vaccination with triennial conventional cytologic screening beginning at 25 years of age. In a resource poor setting, incorporating visual cervix inspection or DNA testing for HPV in at least one visit are cost effective alternatives. ${ }^{1,6}$ In resource rich countries, further HPV DNA testing will improve health benefits compared with status quo screening policies. $^{12}$

A clinical pathway can be used as a useful tool to calculate cost. ${ }^{13}$ The clinical pathway and its schematic algorithm are comprehensive systematic patient care plans for specific procedures. It is a written algorithm or framework for the expected management path for a certain disease or after a specific procedure. They are infrequently used but do not restrict some variance in management ${ }^{14-15}$. As data for costing is not readily available within the national system to calculate cost, this method for costing on intervention activities for cervical cancer management can be used to estimate cost on certain predetermined procedures, surgical intervention and management.

As method for national financing does not come from insurance or other form of national health coverage, data on costing was not easy to retrieve and are subject to confidentiality from the private sectors. Furthermore, the main bulks of cost burden are shouldered upon the public sector from the National Fee Schedule. ${ }^{16}$

The need to study local scenario of cervical cancer economic burden was the main objective in this study. 
Specifically, this study aims to undertake cost analysis of management of cervical cancer cases in Malaysia by government health care providers and to estimate the economic burden of cervical cancer in Malaysian population. the general cost burden of treatment in Malaysia.

\section{METHODS}

The expert panel discussion was initiated in July 2006 and subsequent cost collection for the activities was done till December 2006. The algorithm to determine appropriate management of patients with cervical abnormalities and cancer was based on consensus decisions made by an expert group comprising of gynaecological oncologists, clinical oncologists and cytopathologists. Decisions were also made according o a guideline from the Ministry of Health, Malaysia. ${ }^{3,4}$ The members of the expert group made estimations of the likelihood of choice of treatment modality based on their clinical experience and interim guidelines available in this country which are based on the Besthesda System (2001) and FIGO Committee on Gynaecological Oncology. ${ }^{13}$ These decisions and the likelihood of utilizing these options were made according to all stages of cervical cancer and also according to the respective levels of pre-invasive disease.

To come up with a clinical algorithm that is used for this country and later for costing, the two main references were the expert group opinion and from existing clinical practice guidelines. Some clinical variations are present in the treatment method and this also depends on patients' variability upon presentation and subsequent progression of the disease itself. The treatment algorithm was done as a consensus by an expert's group opinion. Members in that expert team consisted of gynaecological-oncologists, radiologists, cytopathologists, health economist from government teaching and tertiary referral hospitals and public health specialists from Family Health Division, Ministry of Health. The expert group discussion identified different stages in management of cervical cancers, treatment modalities, major and minor procedures and identified common clinical practice patterns among clinicians. Staging of screening was based on Bethesda classification system and staging of cervical cancer was based on International Federation of Gynecology and Obstetrics (FIGO) Classification stages I-IV. ${ }^{13}$
Researchers then imputed the cost for each component by identifying each unit cost and total cost for all inputs needed in the management of cervical cancers in the hospital either as inpatients admissions as well as out patient costs. The components involved from the providers' view were direct and non direct medical cost that includes hospitalization, drugs, physician fees, laboratory tests and radiological procedures. Costing source of information such as surgical procedure cost (direct medical cost and non direct medical cost) was gathered from public hospital billing department and also on the Malaysia Medical Association's Fee Schedule. ${ }^{16}$ The cost of average inpatient days and outpatient clinic visit days was obtained from UKM Medical Centre's Case Mix Report. Costing of Pap smears were obtained from published costing study on Pap smear. ${ }^{9}$

The cost from the patient's point of view only covered the cost of lost productivity that is borne by the patient. The cost of lost productivity was calculated from the total number of sick leave days provided by health carer and was calculated for each stage of disease. Income was based on national income per capita (2005). Sensitivity analysis of base case and its ranges (minimum to maximum cost) were also calculated for all cost components. The clinical pathway treatment algorithm will consist of:

1. Screening of cervical cancer which consists of costs in taking the Pap smear itself (providers cost).

2. Management of pre-invasive state (i.e. ASCUS, CIN I with or without HPV changes till stage CIN III). All procedures involved were taken into consideration and whether the patients required admissions to the wards. This includes cost of Pap smear, cost of Colposcopy, biopsy (cone and punch), and cost of LEEP and clinic visits.

3. Clinical management algorithm of micro invasion and subsequently invasive cancers from stage $1 \mathrm{~A}$ till 4B was prepared by the expert group team. This includes cost of procedures and operations i.e. cost of biopsy (cone and punch), cost of EUA, cost of cystoscopy, cost of hysterectomy (simple and Wertheim's), cost of radiotherapy and cost of chemotherapy. Cost of each repeat clinic visits and days of hospital admissions for one year were also calculated.

This study has received ethics approval from the Ethics Committee Faculty of Medicine and the Ministry of Health Malaysia. 


\section{RESULTS}

The following diagrams show the clinical algorithm according to stage and the clinical activities related to that stage.

\section{Results of pre-invasive cervical cancers algorithm}

From ASCUS, as high as $95 \%$ will be as categorized as ASCUS not otherwise specified (NOS) and will need to repeat a Pap smear in 6 months time. About 30\% from these patients will ultimately need a colposcopy. From the whole of ASCUS seen, only 5\% of cases seen will be classified as neoplastic and colposcopy had to be done on these patients (Figure 1).

For low grade squamous intraepithelial lesions (SIL), as much as $90 \%$ of cases will show HPV changes without $\mathrm{CIN}$ changes and require review in the next 6 months. The remaining $10 \%$ will present as CINI sometimes with HPV changes and needs colposcopy. The remaining $90 \%$ will have satisfactory results whereby $90 \%$ will present with satisfactory results (the transformation zone is visualized completely) with no CIN or HPV changes and a repeat Pap smear done after 6 months. The rest $20 \%$ will go for a biopsy. Unsatisfactory Pap smear results following a negative colposcopy $(10 \%)$ will need a further LEEP (loop electrosurgical excision) procedure done on them (Figure 2).

Patients with HSIL changes will require a colposcopic assessment. $10 \%$ will also need cone biopsy, $60 \%$ will warrant punch biopsy and 30\% will require LEEP to remove the entire cervical transformation zone (Figure 3).

\section{Results of invasive cervical cancers algorithm}

\section{Stage I A 1}

For stage IAI, all the patients will need cone biopsy, examination under anesthesia and cystoscopy. From these, up to $25 \%$ will have to undergo simple hysterectomy to clear the lesion from their cervix (Figure 4).

\section{Stage I A 2}

Patients that is in the stage IA2 stage, will proceed to either surgical or radiotherapy treatment. As much as $90 \%$ of cases will be fit enough for a radical hysterectomy
(Wertheim's operation) while only $10 \%$ of unfit patients will undergo radiotherapy. Radiotherapy will need a few processes i.e. simulation, planning and treatment itself. The surgical procedure will require admission usually up to week or more. Follow up post op will be done after 2 weeks, then 3 monthly for a year, 6 monthly for the next year and yearly for life. Radiotherapy is given at 25-28 times in 5 weeks duration, sometimes with brachytherapy with intra cavity Irradium source under spinal anesthesia (Figure 5).

\section{Stage I B (1 and 2) and II A}

The groupings for this stage are because of the similar treatment modalities and almost similar survival rates of these stages. Patients diagnosed clinically in this stage, will see as much as $70 \%$ going through radical surgical procedure (Wertheim's). From the 70\% undergoing Wertheim's operation, a 33\% proportion of patients post op will still need radiotherapy and chemotherapy (usually with Cisplatinum and antiemetics). 30\% of cases diagnosed with stages IB and IIA not fit for op, will still need to go through radiotherapy (with or without brachytherapy) and chemotherapy (Figure 6).

\section{Stage II B till IV A}

The treatment for disease stage IIB till IVA was classified under the same clinical algorithm. Almost all patients clinically diagnosed in these stages will undergo radiotherapy with concurrent chemotherapy and intra cavity radiation. In $10 \%$ of patients, urethral stenting with $\mathrm{J}$ stents needs to be done and additional blood transfusion. Post treatment, patients will undergo vault smear twice per year, yearly blood tests and CT scans (Figure 7).

\section{Stage IV B}

For disease that has reached stage IVB, in patients presenting with visceral metastasis, these patients which accounts $50 \%$ will need to go through palliative chemotherapyandsomedegreeofpalliativeradiotherapy. Pathway can be differentiated into visceral $(50 \%)$ and non-visceral metastasis $(50 \%)$. In visceral metastasis, patients will be treated with palliative chemotherapy with palliative radiotherapy. In $50 \%$ of cases with nonvisceral metastasis, patients will undergo radiotherapy and chemotherapy. They will need extra psychosocial support (Figure 8). 


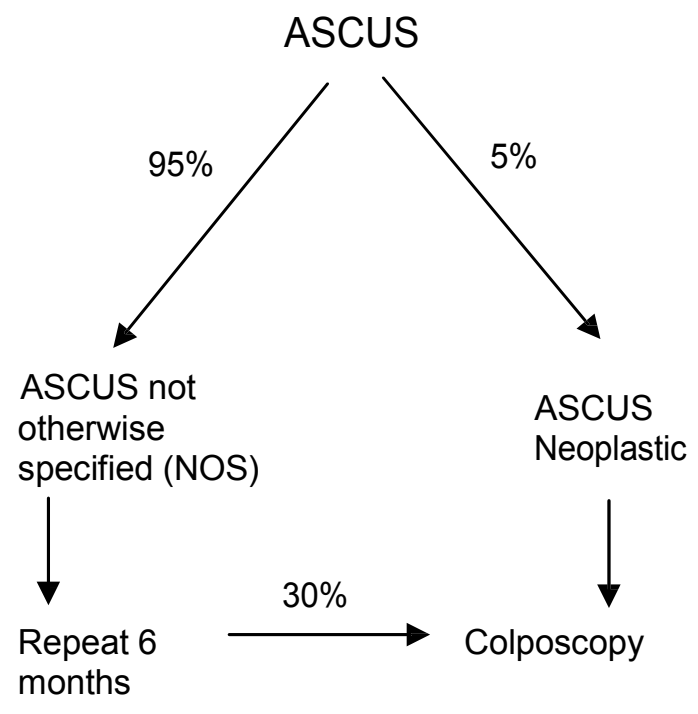

Figure 1.

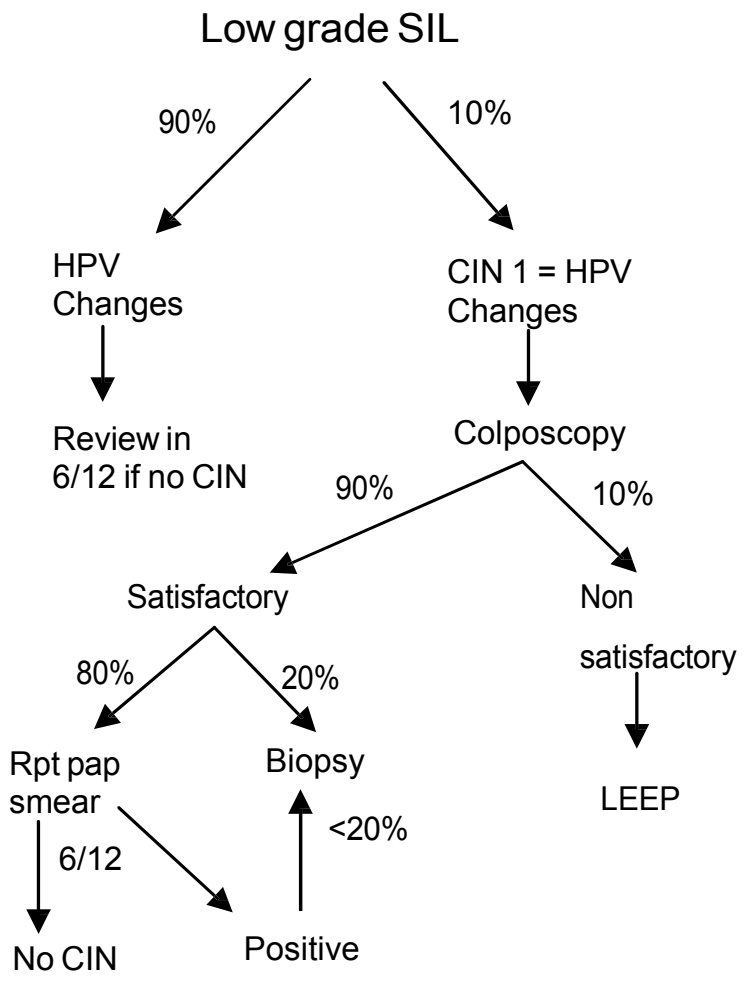

Figure 2.
High Grade SIL (CIN 2,3)

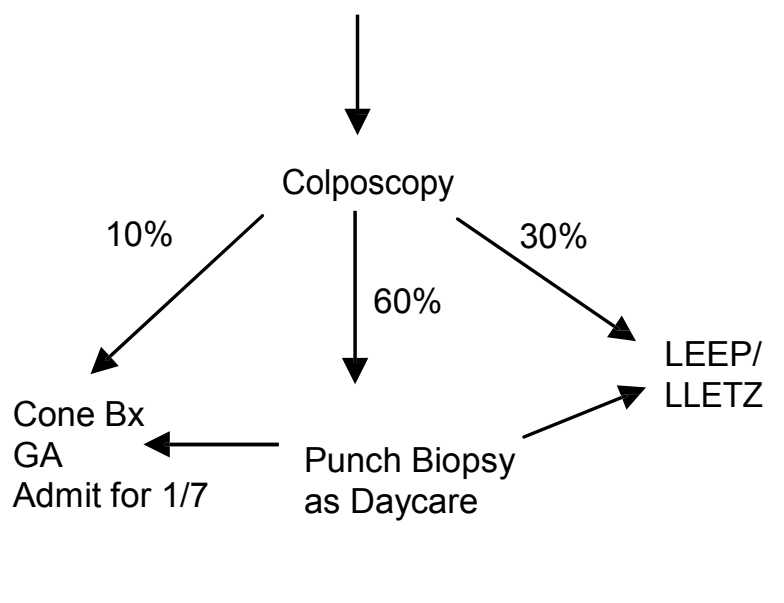

Figure 3.

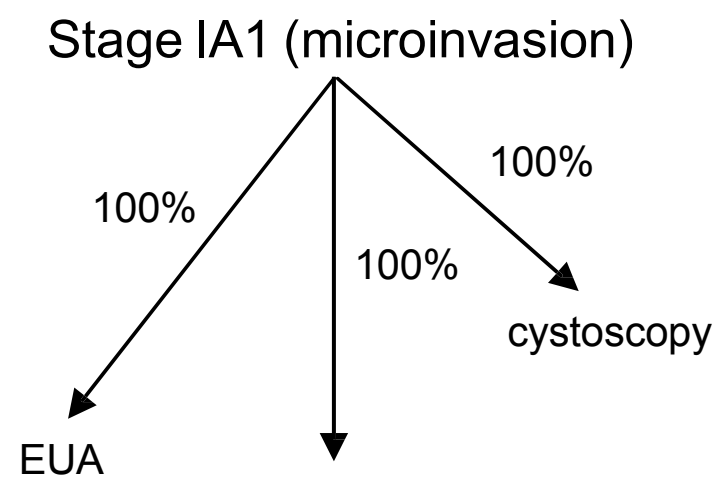

Cone Bx

Figure 4. 


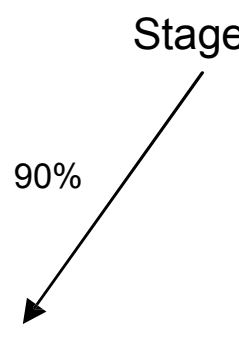

Radicalhysterectomy/ Wertheims + Bilateral lymphadenectomy

Figure 5.

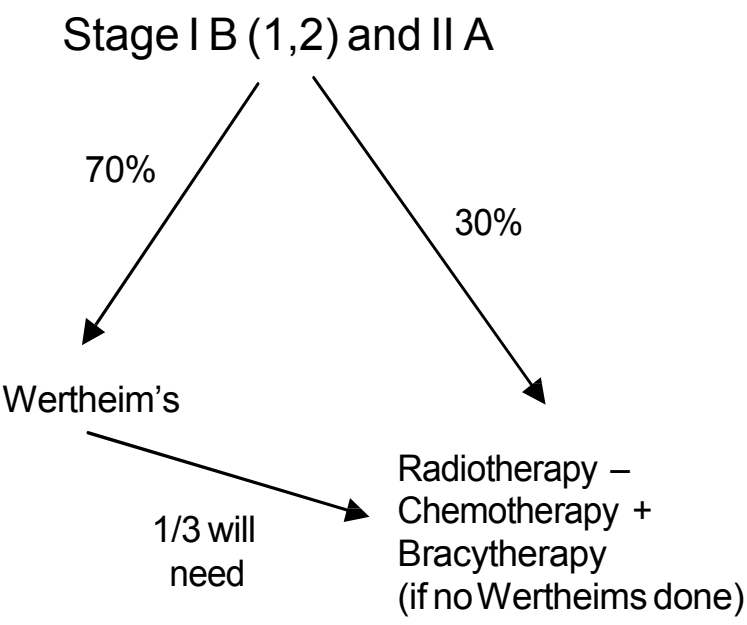

Figure 6.

\section{Cost implications from clinical algorithm}

The treatment cost was divided into two parts namely, treatment of pre-invasive cancers and invasive cancers. From the incidence of cervical cancer in this country ${ }^{2}$ and total female population 20-65 years old, it is estimated that there is over 1193 new cases per year throughout Malaysia. The treatment cost of pre-invasive cancers will cover treatment of ASCUS, CIN I with or without HPV changes (termed LSIL) and CIN II - III (termed HSIL). Treatment of invasive cervical cancers will cover treatment costs from stage IA1 or carcinoma in situ up to stage IVB. The Malaysian cost imputed will be

\section{Stage II B-IV A}

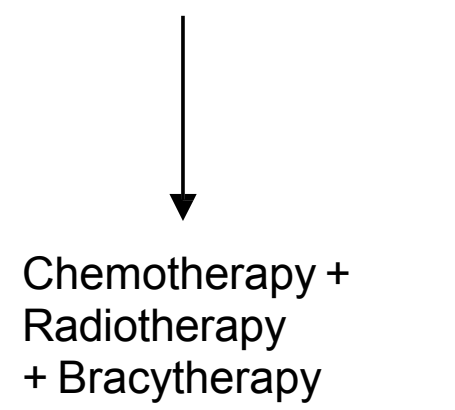

Figure 7.

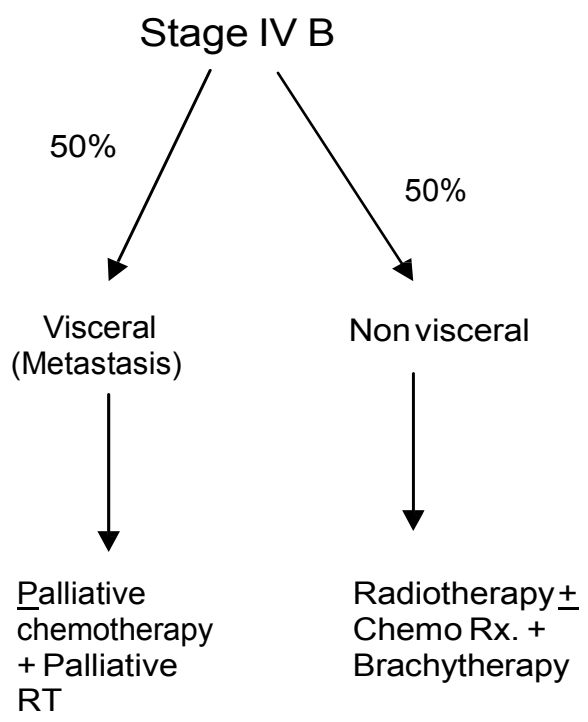

Figure 8.

converted to USD based on the adjusted exchange rate of USD 3.26 for every 1 RM in Jun 2008. Secondary data on national Pap smear screening ${ }^{9}$ was converted to 2007 fiscal year data adjusted for inflation.

\section{Annual cost of pre-invasive cancers treatment}

As much as $47 \%$ from total cost of managing preinvasive cervical cancers came from treating LSIL (CIN I and II). The base cost is USD 196,731.90 (Range: USD 98,365.34-387,418.40). The second largest proportion, $35 \%$ came from treating HSIL or CIN III i.e. base cost of $\$ 146,927.30$ (Range: USD 53,182.82 - USD 
352,642.02). Cost of treating ASCUS was the lowest proportion i.e. $18 \%$ of total cost of managing preinvasive cancers, base cost of $\$ 76,490.49$ (Range: USD 45,609.20 - USD 139,618.40). Total cost of managing pre-invasive cancers was USD 420,149.69 (Range: USD 197,157.67 - USD 879,678.53).

\section{Annual cost of invasive cancers treatment}

The cost of treatment of invasive cancers consists of treatment inclusion of new cases and existing old cases. In Malaysia, there is no current data on existing old cases currently under follow up in the Ministry of Health public hospitals. The cost of treatment of new patients presenting with invasive cancers was around USD 52 billion.

Treatment of advanced stages of cancers i.e. stage IV $\mathrm{B}$ was the most expensive and contributed to $36 \%$ of total cost of managing invasive cancers. Stage IIBIVA followed with $31 \%$ of management cost. Treating cancers stage IB-IIA contributed to $5 \%$ of overall treatment cost. In stage IA2, the cost of treatment contributed to $2 \%$ of total treatment cost of cervical cancers. In stage IA 1 , only $1 \%$ of total cost was incurred from this treatment in this stage of disease. Treatment cost of old cases, estimated to be a third of the total existing cases amounted to $25 \%$ of total treatment cost of managing cervical cancers (Table 1).

This section particularly looks at the proportions of resources allocated to the overall management of cervical cancer diseases in Malaysia. The $10.3 \%$ of total cervical cancer management cost devoted towards Pap smear screening is relatively low, as developed countries devote much of their health care cost on screening rather than treatment of cervical cancer invasive disease stages. Cost of managing invasive diseases (USD 51.5 million annually) takes much of our health care costs based on cervical cancer incidence. It is the main parcel of cervical cancers management or $67.1 \%$. Follow up of existing cases makes up 22\% of cervical cancers management in our model for this country. Cost of managing pre invasive diseases is only $0.6 \%$ from total cervical cancers management cost (Table 2).

Table 1. Annual cost of managing abnormal smears, pre-invasive and invasive Cervical cancer in Malaysia

\begin{tabular}{lccc}
\hline Stages of disease treatment & & Annual Cost (USD) & \\
\hline Pre-invasive Disease & Base & Minimum & Maximum \\
ASCUS & $\$ 76,490.49$ & $\$ 45,609.20$ & $\$ 139,618.40$ \\
CIN I, II & $\$ 196,731.90$ & $\$ 98,365.34$ & $\$ 387,418.40$ \\
CIN III & $\$ 46,927.30$ & $\$ 53,182.82$ & $\$ 352,642.02$ \\
Total Cost & $\$ 20,149.69$ & $\$ 197,157.67$ & $\$ 879,678.53$ \\
\hline Invasive cancer & Base & Minimum & Maximum \\
Stage IA1 & $\$ 857,730.37$ & $\$ 505,369.02$ & $\$ 1,334,213.50$ \\
Stage IA2 & $\$ 1,568,556.75$ & $\$ 939,247.55$ & $\$ 2,688,324.85$ \\
Stage IB-IIA & $\$ 3,622,186.20$ & $\$ 2,392,914.72$ & $\$ 6,760,483.13$ \\
Stage IIB-IVA & $\$ 21,012,237.42$ & $\$ 14,586,321.47$ & $\$ 40,443,627.30$ \\
Stage IVB & $\$ 24,472,522.09$ & $\$ 13,981,546.93$ & $\$ 36,353,918.10$ \\
New Cases & $\$ 51,533,233.44$ & $\$ 32,405,399.69$ & $\$ 87,580,566.87$ \\
\hline
\end{tabular}

Table 2: Annual cost of screening and proportions by management of Cervical cancers in Malaysia

\begin{tabular}{lcc}
\hline Costallocation & USD & $\begin{array}{c}\text { Allocation proportions } \\
\text { by cervical cancer management (\%) }\end{array}$ \\
\hline Screening & $\$ 7,945,794.67$ & 10.33 \\
Managing pre-invasive cases & $\$ 420,149.69$ & 0.55 \\
Managing new invasive cases & $\$ 51,533,233.44$ & 67.01 \\
Managing existing cases & $\$ 17,005,966.87$ & 22.11 \\
Total cost & $\$ 76,905,144.67$ & 100 \\
\hline
\end{tabular}




\section{DISCUSSION}

Cervical cancer and its pre invasive diseases are a major nightmare not only for patients but also for health care providers. The implications of quality of life and years lost to cancer are not discussed in this paper but the public providers' economic burden through activity based costing and diseased population are estimated here. The introduction of population Pap smear screening either opportunistic or mandatory, aims to reduce cervical cancer before the disease ravage its women population. However, a lot of socio-cultural and religious entities play a role in the acceptance of cervical screening and also with the introduction of a new HPV vaccination program recently proposed for the country.

The low priority and portion of cost in the management of cervical cancers is very obvious in this model. This goes hand in hand with the low utilization of cervical cancer screening cost and its proportion. Thus when the women come to the attention of medical entities, the disease would have become widespread in local, regional or distant cancer. Treatment targeted at the late stages of cancers diseases, not only have low success rate in treatment, it would translate into high administrative and costly interventions that could have been thwarted if intervention had been started at an earlier stage. This has implications on policy makers in this country of the high cost impact of cervical cancers in this country, the late stages we are catching them and how women in this country place such a low priority for early screening and interventions to save their lives.

Malaysia's screening strategies which are mostly opportunistic and not mandatory, but routinely organized when mothers come during post natal visits, during family planning services or during screening programs. In the private sectors, coverage of Pap smears is done by general physicians or by panel health care providers. Also an opportunistic screening and depends entirely on the willingness of women participants. The coverage differs with established screening strategies such as in developed countries where by screening cost makes up a high proportion of overall cervical disease management. This high uptake of women screening has led to an absolute decrease in cervical cancer cases and women are seen at an earlier stage of disease. This leads to reduced management cost and reduced health complications, higher quality of life and increased survival on the affected women.
The country spends about RM 24.4 billion (USD 7.5 billion) on total health expenditure in year 2006 or about $4.3 \%$ of its country GDP on health care. With such a high cost of cervical cancer management especially in the later stage of disease and continuation of management for old cases follow ups and treatments, it has led to a high burden on healthcare of this country. That amount of monetary resources must be diverted into more useful and cost effective methods to reduce this disease among women in Malaysia. Some of these proposals include a detailed analysis of the HPV vaccination in view of mass vaccination of girls and adolescent in this country with continuation of recommended Pap smear screening using the national guideline. However the targeted women population covered through screening must be increased to make it cost effective.

\section{CONCLUSION}

The use of clinical pathways in activity based costing to calculate costs can be used in imperative cost calculations for certain diseases that have high impact on quality of life and economic burden. The use in cervical cancer management has established some light on the extensive burden to health care providers through screening and treatment management of confirmed cases.

\section{Acknowledgement}

We thank Dr Maimoon Alias, Dr Majdah Mohamed, Dr Murali G. Muralitharan from the Ministry of Health, Dr Fuad Ismail, Dr Sharifah Noor Akmal, Dr Seri Suniza Sufian and Dr Ahmad Zailani Mohd Dali from the Universiti Kebangsaan Malaysia for their input during the first clinical pathway workshop.

\section{Source of Funding}

This study was funded by the Merck, Sharp and Dome through the Public Health Specialist Association of Malaysia.

\section{REFERENCES}

1. Goldie SJ, Kohli M, Grima D, Weintein MC, Wright TC, Bosch FX, Franco E. Projected clinical benefits and costeffectiveness of a human papillomavirus $16 / 18$ vaccine. Journal of the National Cancer Institute. 2004; 96:604-15. 
2. National Cancer Registry. Second report of the national cancer registry cancer incidence in Malaysia. 2003.

3. Guidebook for Pap smear screening. Division of Family Health Development. Ministry of Health Malaysia. 2004.

4. Clinical Practice Guideline: Management of Cervical cancers. Ministry of Health Malaysia. 2003.

5. Morantz CA. ACOG releases guidelines for management of abnormal cervical cytology and histology. Am Fam Physician. 2006;73:719-23.

6. Mandelblatt JS, Lawrence WF, Gaffikin L, Limpahayom KK, Lumbiganon P, Warakamin S, et al. Costs and benefits of different strategies to screen for cervical cancer in lessdeveloped countries. J Nat Cancer Instit. 2002;94:146983.

7. Garland SM, Hernandez-Avila M, Wheeler CM, Perez G, Harper DM, Leodolter L, et al. Quadrivalent vaccine against human papillomavirus to prevent anogenital diseases. New England J Med. 2007;356:1928-43.

8. Markowitz LE, Dunne EF, Saraiya M, Lawson HW, Chesson H, Unger ER. Quadrivalent human papillomavirus vaccine; recommendations of the Advisory Committee on Immunization Practices. 2007: 56(RR-2):1-24.

9. N, Triaspolitica. "Mengenal Penyakit Kanker, Jenis, Gejala, Penyebab Berikut Pengobatan Kanker." Mau Nanya Dong Dok. N.p, 20 June 2017. Web. 28 June 2017. $<$ https://nanyadongdok.blogspot.com/2017/06/menge nal-penyakit-kangker-jenis-gejala.html $>$.
10. Brown RE, Breugelmans JG, Theodoratou D, Benard S. Costs of detection and treatment of Cervical cancer, cervical dysplasia and genital warts in the UK. Current Med Research and Options. 2006;22:663-70.

11. Balasubramani L, Tidy J. Hope for cervical cancer screening. Hospital Doctor. 2006.

12. Kim JJ, Thomas CW, Goldie SJ. Cost-effectiveness of human papillomavirus DNA testing in the United Kingdom, the Netherlands, France and Italy. J Nat Cancer Instit. 2005; 97: 888-95.

13. Wong C, Visram F, Cook D, Griffith L, Randall J, O'Brien $\mathrm{B}$, et al. Development, dissemination, implementation and evaluation of a clinical pathway for oxygen therapy. Canadian Medical Association Journal. 2000; 162:29-33.

14. Panella M, Marchisio S, Stanislao F. Reducing clinical variations with clinical pathways: do pathways work? Intl J Quality in Health Care. 2003; 15:509-21.

15. Loeb M, Carusone SC, Goeree R, Walter SD, Brazil K, Krueger P, et al. Effects of a clinical pathway to reduce hospitalizations in nursing home residents with penumonia. J Am Med Assoc. 2006;295:2503-10.

16. FIGO Committee on Gynaecologic Oncology. Staging classifications and clinical practice guidelines for gynaecologic cancers. Intl J Gynaecol Obstet. 2000;70:207312. 